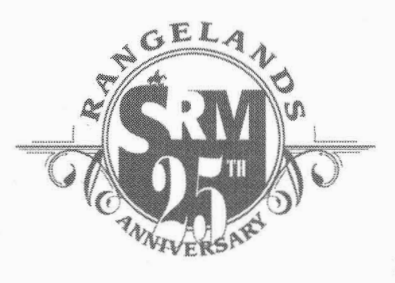

\title{
People From The Past C. Wayne Cook
}

Editor's Note: As we commemorate the $25^{\text {th }}$ Anniversary of Rangelands magazine, we pay tribute to SRM members who have helped shaped the profession of rangeland management.

\section{By Joe Trlica and Dennis Child}

\section{Wayne Cook has} been involved in Range Science education, research and outreach for more than 60 years. Even though Cook officially retired from Colorado State University (CSU) in 1980, he remains active and is producing web-based educational products for the practitioner and interested public concern-

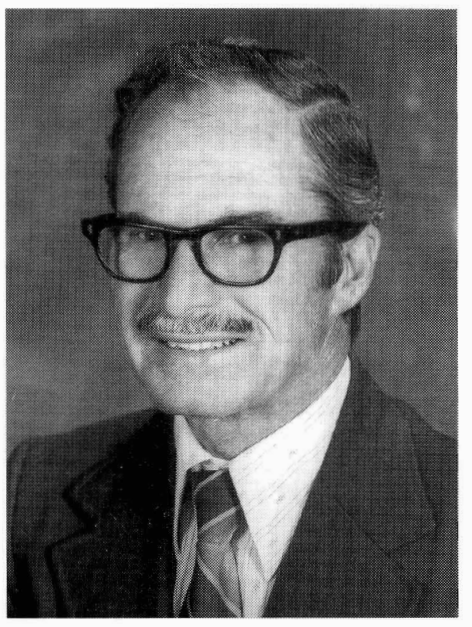
ing rangeland ecosys-

tems and their effective management.

Cook has been a leader in formation and development of the range science profession and in the Society for Range Management (SRM). He has been a member of SRM since its inception and has served in several leadership positions within the Society including President and chair of the Education Committee. Many agree, few individuals have been as active and contributed so much to the range profession.

Cook had a long and distinguished career in teaching, administration and research. He worked at the College of Southern Utah, Utah State University, and in 1968 came to Colorado State University. During his academic career he trained more than 2,000 students in range management, many of whom entered into productive careers in teaching, research, land management or administration.

He truly institutionalized the ecosystem approach in the range curriculum. As head of the Range Science Department at CSU he built a program where range undergraduates increased to more than 200 students and graduate student numbers in- creased to more than 60 . The CSU range department was the first department to be accredited by SRM.

Cook made many outstanding contributions to range management through his research efforts. He contributed more than 100 major scientific publications in range nutrition, range utilization and management, range rehabilitation, and range ecology. He was a pioneer in computer based applications for more efficient range and ranch planning.

Cook has been an ardent supporter of the range livestock industry as well. He has conducted and participated in many short courses, field days, and extension programs designed to improve rangeland management in the West and in other nations.

$\mathrm{He}$ is truly a rangeland professional that is admired and respected by those who have worked with him. His dedication, energy and enthusiasm for the advancement of rangeland ecosystem science has resulted in a better understanding of the myriads of interactions that affect complex rangeland ecosystems.

C. Wayne Cook presently lives in Ft. Collins, Colorado, and says he dedicates his years of work and articles to his wife Eula who supported him in every way. "Eula edited and typed all my work through graduate school at three different institutions. She and I worked together for all my degrees and on all my manuscripts, and she deserves much of the credit," he says. Sadly, Eula passed away March 29, 2002.

As a researcher and author, Cook recognizes the importance of having a publication such as Rangelands. He says the magazine has served the purpose of being an outlet for personal research and allows a varied audience to read about range science.

\footnotetext{
For access to Dr. Cook's articles visit www.cnr.colostate.edu/RES.
} 